\title{
Recognizing the Business Models Types in Tourism Agencies: Utilizing the Cluster Analysis
}

\author{
Abdolmajid Mosleh ${ }^{1}$, Saeed Nosratabadi ${ }^{1} \&$ Parvaneh Bahrami ${ }^{1}$ \\ ${ }^{1}$ Business Management Department, Persian Gulf University, Bushehr, Iran \\ Correspondence: Saeed Nosratabadi, Business Management Department, Persian Gulf University, Bushehr, Iran. \\ Tel: 98-935-644-4712. E-mail: saeed.nosratabadi@gmail.com
}

Received: December 8, 2014

Accepted: December 29, 2014

Online Published: January 25, 2015

doi:10.5539/ibr.v8n2p173

URL: http://dx.doi.org/10.5539/ibr.v8n2p173

\begin{abstract}
Success in a business depends on different factors. One of these factors is design and implementation of a unique business model. This model is representation of a pattern commercializing innovations and ideas. Indeed, this model illustrates the profitability boundaries caused by innovations. Hence, this study was conducted to recognize the business model types used by Tehran's Tourism agencies. The main question of the study is what kinds of business model are used by Tehran's tourism agencies? The utilized framework to analysis the business models, in this study, comprises four dimensions service, target market, infrastructure management, and financial aspects. This study was conducted in Tehran's tourism agencies in $2014(\mathrm{n}=110)$. A questionnaire was administered for data collection. Hierarchical clustering using SPSS 19.0 used to analyses data and acquires the main purpose of the study. Findings revealed that Tehran's tourism agencies, mainly, use three kinds of business model which are Financial Model Based Business Model, Customer Based Business Model, and Service Based Business Model. It was also illustrated that most of Tehran's tourism agencies were utilizing Service Based Business Model.
\end{abstract}

Keywords: business model, financial model based business model, customer based business model, service based business model, hierarchical cluster analysis

\section{Introduction}

Business model is almost a new concept which has been widespread in management and organization literature since 1990s (Lambert \& Davidson, 2012). The concept targets the business logic; as it elaborates what a business actually does and how it makes money. Indeed, the business model serves as a building plan that allows designing and realizing the business structure and systems that constitute the company's operational and physical form (Osterwalder, Pigneur, \& Tucci, 2005). Although there is not a consensus on what is a business model due to the dynamic nature of this concept, all of the authors have related this concept to the creation and deliver of value by a business. According to Magretta business models are like stories illustrating how an organization work. Magretta hold the believe that a good business model answer the Drucker's questions: Who is the consumer? What is the consumer's value? (Magretta, 2002). Also, Johnson, Christensen, and Kagermann. (2008) consider business model as a four-dimension model in which the collaboration among these four dimensions create and deliver value. These dimensions are 1) consumer's value proposition 2) profit formula 3) key sources and 4) key activities (Johnson et al., 2008). On the other hand, it is necessary to choose a model so as to success in competition regarding change trends, treats, and opportunities. Besides, it is possible to choose different combinations for a business model; because, there are several options in each business model component. Thus, correspond to each of these compounds, unique models will be shaped. All businesses weather consciously or unconsciously have their own business model $(\mathrm{Hu}, 2013)$. The Awareness about this concept makes able managers to consciously choose their business model based on their strength and weakness and the environmental opportunities and threats. Identifying the type of business model which is using by a business can facilitate analyzing and predicting the trends and enable decision makers to dynamically response to changes and guarantee profitability. On the other hand, identification of the current situation is the first step on the choice of strategic decisions related to business model.

On the other hand, research in business model area, which propose a business model framework, can be divided into two categories. The first category contains research providing a conceptual framework for a special industry 
(e.g. Bouwman, Van der Spek, \& Faber (2005) in insurance industry, Weiner (2011) and currei (2004), Pateli \& Giaglis (2003), Osterwalder \& Pigneur (2002), in lectronic business, Pousttchi, Schiessler, \& Wiedemann (2007) in mobile industry). The second category includes the research developing a general framework regardless the features of special industry or a business (i.e. Osterwalder, Pigneur, \& Tucci, 2005; Tikkanen, 2010; Storbacka \& Nenonen, 2010). On the other hand, the research conducted in the common fields of tourism and business model mainly have focused on e-business models (Zhang, 2007; Ping, 2010; Yuhang \& Xiaoling, 2010) and tourism e-commerce business model (Zhang, 2009; Corigliano \& Baggio, 2004). Nonetheless, not only has not studied the types of tourism business model in the literature, but also it is not provided a framework for analyzing tourism agencies' business model. Hence, this study aimed to bridge the gap and provide a method to identify the business model kind utilized by tourism agencies. Hence, the current study conducted to identify business model types utilizes by Tehran's tourism agencies. In other words, this study is going to answer the question below:

What kinds of business model are utilized by Tehran's tourism agencies?

\subsection{Tourism Business Model}

Regarding the lack of a business model associated with tourism agencies in the literature, this study approved the Osterwalder et al. (2005) business model framework as the fundamental model of the study. These model comprises 4 main components namely, product/service, customer interface, infrastructure management, and financial model. According to the dynamic nature tourism business model, changes occurred in the model. As a result, two of the basic elements in the model (value configuration and distribution channels) were omitted, because of the lack of their application in the tourism agencies' business models. On the other hand, regarding the effect of technology on nature of businesses and the presentence of this element in the purposed models of some authors (Bouwman et al., 2005; Linder \& Cantrell, 2000); this element is added to the model as one of the subcomponents of infrastructure management dimension. The model used in this study has summarized into table 1 . As it is clear, each component has its own subcomponents that their definition is provided in table 1 too.

Table 1. The definition of tourism business model components

\begin{tabular}{|c|c|c|c|}
\hline Main components & Subcomponents & Definition & Reference \\
\hline Product/service & Value proposition & $\begin{array}{l}\text { Provides a comprehensive view of a company's combination of } \\
\text { products and services }\end{array}$ & $\begin{array}{l}\text { Osterwalder et al. } \\
\text { (2005) }\end{array}$ \\
\hline \multirow[t]{2}{*}{ Customer Interface } & Target Customer & $\begin{array}{l}\text { Explains the segments of customers to which the company wants } \\
\text { to offer value. }\end{array}$ & $\begin{array}{l}\text { Osterwalder et al. } \\
(2005)\end{array}$ \\
\hline & Relationships & $\begin{array}{l}\text { Describes the type of links a company creates between itself and } \\
\text { its different segments of customers. }\end{array}$ & $\begin{array}{l}\text { Osterwalder et al. } \\
\text { (2005) }\end{array}$ \\
\hline \multirow[t]{3}{*}{$\begin{array}{l}\text { Infrastructure } \\
\text { Management }\end{array}$} & Core competency & $\begin{array}{l}\text { Illustrates the competencies necessary to perform the company's } \\
\text { business model. }\end{array}$ & $\begin{array}{l}\text { Osterwalder et al. } \\
\text { (2005) }\end{array}$ \\
\hline & Partner network & $\begin{array}{l}\text { Depicts the network of cooperative agreements with other } \\
\text { companies necessary to efficiently offer and commercialize value. }\end{array}$ & $\begin{array}{l}\text { Osterwalder et al. } \\
\text { (2005) }\end{array}$ \\
\hline & Technology & $\begin{array}{l}\text { Is a description of the technical functionality required to realize } \\
\text { the service. }\end{array}$ & Bowman, (2005) \\
\hline \multirow[t]{2}{*}{ Financial Model } & Cost structure & $\begin{array}{l}\text { Outlines the monetary consequences of the means used to } \\
\text { implement the business model. }\end{array}$ & $\begin{array}{l}\text { Osterwalder et al. } \\
(2005)\end{array}$ \\
\hline & Revenue model & $\begin{array}{l}\text { Summarizes the way a company makes money through a variety } \\
\text { of revenue flows. }\end{array}$ & $\begin{array}{l}\text { Osterwalder et al. } \\
\text { (2005) }\end{array}$ \\
\hline
\end{tabular}

\section{Methodology}

This is an applied research; that is why, the expected results can be utilized by tourism agencies to improve their performance. On the other hand, this research is classified into survey- analysis research in which data collected via literature (secondary data) and a questionnaire (primary data) distributing among Tehran's tourism agencies (2014).

\subsection{Measurement Tool}

The first step for recognizing the business model types in tourism agencies, is analyzing their business model. A questionnaire based on tourism agencies' business model suggested by current study, was administered and the 
5-point Likert's scale was used to evaluate the participants' responses. As it is cleared in the table 2, the questionnaire comprised 42 questions.

Table 2. Structure of the questionnaire

\begin{tabular}{lll}
\hline Business Model Dimensions & Subcomponents & Numbers \\
\hline Service & Value Proposition & 10 \\
Customer Interface & Target Customer & 4 \\
& Relationship & 3 \\
Infrastructure Management & Core Competency & 4 \\
& Partner Network & 3 \\
& Technology & 6 \\
Financial Model & Revenue Model & 8 \\
& Cost Structure & 4 \\
Sum & & 42 \\
\hline
\end{tabular}

Cronbach's alpha was counted in order to evaluate the reliability of the questionnaire. As table 3 reveals, since the Cronbach's alpha coefficients for all variables are more than 0.7 , it can be concluded that the questionnaire has the required reliability.

Table 3. Results of the questionnaire reliability

\begin{tabular}{lcc}
\hline \multicolumn{1}{c}{ Latent Variables } & Cronbach's Alpha & Numbers \\
\hline Value proposition & 0.81 & 10 \\
Target customer & 0.88 & 4 \\
Relationships & 0.76 & 3 \\
Core competency & 0.77 & 4 \\
Partner network & 0.88 & 3 \\
Technology & 0.76 & 6 \\
Revenue model & 0.82 & 8 \\
Costs structure & 0.70 & 4 \\
\hline Questionnaire & 0.79 & 42 \\
\hline
\end{tabular}

Content validity and construct validity were examined to assess the validity of the questionnaire. In order to assess the Content validity, the questionnaire submited to three of assistant professors at Persian Gulf University and according to their comments the required changes took place. So as to assess the construct validity factor analysis and SPSS 19.0 software used. Parameters evaluated in this test are Kaiser-Meyer-Olkin Measure of Sampling Adequacy and Bartlett's test of significant level. The results of these tests are shown in Table 4.

Table 4 . The results of factor analysis for content validity and construct validity

\begin{tabular}{lll}
\hline Variables & KMO & Bartlett's Test \\
\hline Value proposition & 0.6 & 0.00 \\
Target customer & 0.73 & 0.00 \\
Relationships & 0.64 & 0.00 \\
Core competency & 0.57 & 0.00 \\
Partner network & 0.57 & 0.00 \\
Technology & 0.67 & 0.00 \\
Revenue model & 0.65 & 0.00 \\
Costs structure & 0.68 & 0.00 \\
\hline
\end{tabular}


It is worth mentioning, Bartlett's significant level must be less than 0.05 and KMO must be more than 0.5 to be considered acceptable (Cecchetto \& Pellanda, 2014). Since, the mentioned indices are in the acceptable range, it can conclude the questionnaire has an acceptable validity.

\subsection{Participants and Procedures}

As it mentioned above, Tehran's tourism agencies formed the population of this study. According to the Iranian Cultural Heritage and Tourism Organization, there were 1103 tourism agencies in Tehran in 2014. In order to determine the sample size the formula below was used.

$$
n=N\left(Z_{\alpha / 2}\right)^{2}\left(\delta_{x}\right)^{2} \div\left[\varepsilon^{2}(N-1)+\left(Z_{\alpha / 2}\right)^{2}\left(\delta_{x}\right)^{2}\right]
$$

Where: $\mathrm{N}=$ Population size, which was equal to $1103, \mathrm{Z}_{\alpha / 2}=\mathrm{Z}$-value, considered $95 \%, \delta_{\mathrm{x}}=$ standard deviation of the population, or the reason that the standard deviation of population did not exist, the standard deviation of the sample counted and generalized to the population. Hence, $\mathrm{n}=30$ was considered, and the standard deviation of these samples, which was used in the formula, was determined to be equal to 0.39 , and $\varepsilon=$ sampling error its value considered to be equal to 0.07 . Regarding the values, the sample size determined to be approximately 108 :

$$
n=1103(1.96)^{2}(0.39)^{2} \div\left[(0.07)^{2}(1103-1)+(1.96)^{2}(0.39)^{2}\right]=107.7
$$

It was decided to choose 110 tourism agencies as sample size. Hence, the 110 tourism agencies chose randomly from the list of tourism agencies released by the Iranian Cultural Heritage and Tourism Organization. A simple random sampling was used in this study and questionnaire submitted to the managers and CEOs. At the same time, a member of the research team was present so as to cope with any possible questions or misunderstandings. The questionnaires were returned to the research team as soon as they were completed. An approximately 2 months' data collecting period was planned and finally, data associated to 110 of the tourism agencies had been collected ( $100 \%$ response rate).

\subsection{Statistical Analyses}

Cluster Analysis is a statistical method which classifies the objects into two or more discordant groups; as its aim is to explore the system of objects. In cluster analysis, the objects are classified to groups based on their traits. Clusters are formed in such a way that objects of associated with each cluster have the most similarity with each other and have the most difference with objects located at other clusters.

The methodology classifies the data without any presumption about the number of clusters (groups) and the number of clusters will determine after cluster analysis. Hence, cluster analysis is defined as a statistical method in which objects are dedicated into homogenous categories in order to create a scientific classification (Bayazidi, Oladi, \& Abbasi, 2011). Cluster analysis, similar to factor analysis, dose not distinguish between dependent variables and independent variables. The method diminishes the number of objects by clustering them into slighter groups.

\subsubsection{Cluster Analysis Technique}

Due to the fact that it is not usually clear how many groups or clusters occurs in sample, two steps are suggested for cluster analysis:

1) Hierarchical Cluster Analysis;

2) Clustering algorithm selection.

Hierarchical cluster analysis is a statistical method to explore relatively homogenous clusters form objects which are adopted based on a measured traits. Firstly, the analysis considers each object as a cluster. After that, the analysis gradually blends clusters and declines the number of clusters at each step till to form one cluster (Bayazidi, Oladi, \& Abbasi, 2011). Clustering method utilizes dissimilarity or distance between objects during the formation of the clusters. To determine the distance "Square Euclidean Distance" is one of the most famous method. There are numerous methods with different criteria and it is possible to obtain different categories form the same data. Ward method is one of the most popular and best clustering method. Because it uses ANOVA to assess the distance between cluster. The cluster membership counts based on total sum of derivatives square of the average of clusters. Data were entered into SPSS 19.0 to analysis. As above mentioned, to answer the research question and recognize the types of used business models among Tehran's tourism agencies cluster analysis was used.

\section{Results}

\subsection{Socio-Demographic Information}

Sixty-seven of 110 participants, i.e., $61 \%$ of them, were male, and $39 \%$ were female. Seventy-three $(66.4 \%)$ of 
the participants had Bachelor's degrees, and 37 of them (33.6\%) had a Master's degrees. Thirty percent of the participants had less than five years of experience in managing a tourism agency; only $7 \%$ of them had more than 20 years of experience. Thirty-one percent of the tourism agencies had been in business less than five years, while only $3 \%$ of them had been in business more than 20 years.

\subsection{Findings}

After Cluster Analysis and Ward Methodology by using SPSS 19.0, three main clusters appeared. In other word, the business models which were chosen by Tehran's tourism agencies were divided into three categories based on their features. As table 3 shows, 27 tourism agencies placed in the first cluster. It means the business model of these 27 agencies had the most similarity and their business model had the most deference with other clusters. The second cluster comprised 38 tourism agencies which were $34 \%$ of sample size. Finally, $40.09 \%$ sample size (i.e. 45 tourism agencies) placed in third cluster.

Table 3. The result of ward method analysis

\begin{tabular}{lccc}
\hline Clusters & Frequency & Percent & Cumulative Percent \\
\hline Cluster 1 & 27 & $24.5 \%$ & $24.5 \%$ \\
Cluster 2 & 38 & $34.5 \%$ & $59 \%$ \\
Cluster 3 & 45 & $41 \%$ & $100 \%$ \\
\hline Sum & 110 & $100 \%$ & \\
\hline
\end{tabular}

In the next step and after clarifying the clusters and placing each tourism agency in these clusters, the business model of each cluster was probed. In this step, the mean of the values associated with each business model component, which obtained by all agencies in each cluster, counted as they are provided in the table 4 .

As table 4 shows, in the group 1 (cluster 1) "financial model" has reached the most value while "target customer" has obtained the most value in the group 2 and "service" has gained the most value in the group 3.

Table 4. The mean of the values of business model components at three recognized categories

\begin{tabular}{lccc}
\hline Business model components & Cluster 1 & Cluster 2 & Cluster 3 \\
\hline Service & 2.3 & 2.53 & 3.13 \\
Target Customer & 2.25 & 3.13 & 2.81 \\
Infrastructure Management & 2.11 & 2.13 & 2.8 \\
Financial Model & 2.92 & 2.92 & 3.08 \\
Business model's value & 2.4 & 2.68 & 2.96 \\
\hline
\end{tabular}

\section{Discussion}

A component obtaining the biggest average among the other business model components in a cluster means the tourism agencies associated with that cluster had a more concentration on that component; in other word, they effectively performed on that element than other business model components. The study labeled each cluster based on the name of component taking the largest average. Hence, the three appeared clusters named: Financial Model Based Business Model, Customer Based Business Model, and Service Based Business Model.

\subsection{Financial Model Based Business Model}

According to the findings, financial model had the largest average in the first cluster; thus, this cluster labeled as Financial Model Based Business Model. As mentioned above, financial model refers to cost structure and income model. The common feature of tourism agencies categorized into this cluster is they had more variety in income ways. In other words, these tourism agencies had tours with more vary destination goals. For instance, educational tours, cultural tours, sport tours, visiting expo tours, and thing like this. On the other hand, addition to tours, these agencies had other income ways such as holding an exhibitions crafts or music in Tehran. Moreover, the most of cost structure of these agencies focused on activities which were aimed to the value creation processes. Consequently, Financial Model Based Business Model can be defined as a model in which 
most of the concentration is on the ways to make money and its cost structure are directed toward value creation activities. Hence, the business model of tourism agencies taking place into this cluster labeled financial model based business model. According to findings, the first goal of such tourism agencies is to find a value having the ability to persuade consumers pay for. After that, these agencies focus on the way payments have been made. One of the most important factors in financial model based business model is pricing model (Osterwalder, Pigneur, \& Clark, 2010). Pricing model has a direct relationship with revenue streams and it can persuade or dissuade costumers to pay.

\subsection{Customer Based Business Model}

Table 4 reveals that the element of target customer had the largest average (3.13) among other elements in the second cluster. Hence, this cluster labeled customer based business model. The agencies associated with this cluster had more variety in customers and the customer interface ways. The varied criteria in market segmenting leads to varied customer. On the other hand, the varied customer leads to varied customer interface. Thus, Customer based business model can be defined as a model in which all business model components are directed toward cove more customers and effectively perform in customer interface.

\subsection{Service-Based Business Model}

Ultimately, whereas the element of service, in comparison with other business model components, gain the largest average in third cluster, the business model of tourism agencies of associated with this cluster labeled as service-based business model. This means that the tourism agencies having more variety in their services and value proposition were devoted in the third cluster. Indeed, most of tourism agencies studied by this study dedicated in the third cluster (45 tourism agencies out of 110). In other words, the results demonstrated that $40.9 \%$ of tourism agencies utilized service-based business model.

The last row of table 4 reveals an average each cluster obtained in its own business model. According to the table, the least average of business model was belong to agencies located in first cluster. It means, the tourism agencies utilizing financial model-based business model had the least score in their business model. While, tourism agencies of third cluster using service-based business model had the most score in business model. This could be because the service-based business models, had more variety in their services. Hence, this variety in service cover more variety customer. To response to these customer the tourism agencies needed to have stronger infrastructure management. On the other hand, more variety in customers and services lead to more variety ways to make money. Thus, it makes sense that the business model of tourism agencies of third cluster take a more score.

\section{Conclusion}

The finding illustrated that Tehran's tourism agencies, generally, utilized three kinds of business model. The first model was financial model-based business model, which had the most concentration on this business model component. Some of tourism agencies utilized customer-based business model. In this category, tourism agencies had a more focus on the component of target customer. Finally, it was illustrated that the third kind of business model utilized by the rest of Tehran's tourism agencies was service-based business model. Most of Tehran's tourism agencies $(40.9 \%)$ had a service-based business model. The distinguishing feature of this kind of tourism agencies was the more variety in their offered service. Surprisingly enough, the tourism agencies using service-based business model, also had a more efficiency in their business model. According to the findings, it is suggested that Tehran's tourism agencies use the service-based business model.

Regarding the findings, recommendations are suggested to tourism agencies' managers based on the type of their business models. It is recommended that the mangers using financial based business model to identify, first of all, the values convince costumers to pay for. Then, they have to recognize the ways to make money and illustrate the proportion of each way than the total revenue. At last, they have to compare the ways costumers tend to pay with the current ways. Moreover, the managers should identify and prioritize exposed cost in the value creation and value offering process. On the other hand, it is recommended to managers using costumer-based business model, firstly, to identify who are they value creating for? And who are their important costumers? Furthermore, recognizing appropriate ways to reach costumers is one of the most important activities that these managers should do. It is very important to coordinate all business model components; particularly, the coordination of the ways to communicate with costumers and other business model components. Finally, it is suggested to the managers preferring to use service-based business model to recognize, at first, their value they are creating and offering to the costumers. After that, they must illustrate what costumers' needs they are satisfying? And ultimately, for the reason that it is possible the needs of different segments of a market are different, the managers have to identify what portfolio of value proposition they must offer to what market segment. 


\section{References}

Bayazidi, E., Oladi, B., \& Abbasi, N. (2011). Analyzing the questionnaire based data using SPSS 19.0. Tehran, Abed.

Bouwman, H., Van der Spek, J., \& Faber, E. (2005). Connecting future scenarios to business models of insurance intermediaries. 18th Bled E-Conference, Bled, Slovenia.

Cecchetto, H. F., \& Pellanda, L. C. (2014). Construction and validation of a questionnaire on the knowledge of healthy habits and risk factors for cardiovascular disease in schoolchildren. Jornal de Pediatria, 90(4), 415-419. http://dx.doi.org/10.1016/j.jped.2013.12.010

Corigliano, M. A., \& Baggio, R. (2004). Italian tourism on the internet - new business models. The Tourism And Leisure Industry: Shaping the Future, 301-316.

Currei, W. L. (2004). Value creation from the application service provider e-business model: the experience of four firm. Journal of Information Management, 17(2). http://dx.doi.org/10.1108/17410390410518763

Fornell, C., \& Larcker, D. (1981). Evaluating structural equation models with unobservable variables and measurement error. Journal of Marketing Research, 18, 39-50. http://dx.doi.org/10.2307/3151312

Hu, B. (2013). Linking business models with technological innovation performance through organizational learning. European Management Journal, 32(4), 587-597. http://dx.doi.org/10.1016/j.emj.2013.10.009

Johnson, M. W., Christensen, C. C., \& Kagermann, H. (2008). Reinventing your business model. Harvard Business Review, 86(12), 50-59.

Lambert, S. C., \& Davidson, R. A. (2012). Applications of the business model in studies of enterprise success, innovation and classification: An analysis of empirical research from 1996 to 2010. European Management Journal, 31(6), 668-681. http://dx.doi.org/10.1016/j.emj.2012.07.007

Linder, J., \& Cantrell, S. (2000). Changing business models: Surveying the landscape. Accenture, Institute for Strategic Change.

Magretta, J. (2002). Why business models matter. Harvard Business Review, 33-36.

Osterwalder, A., Pigneur, Y., \& Tucci, C. L. (2005). Clarifying business models: Origins. Communications of Association for Information System, 15(16).

Osterwalder, A., \& Pigneur, Y. (2002). An e-business model ontology for modeling e-business. 15th Bled Electronic Commerce Conference e-Reality: Constructing the e-Economy, Bled, Slovenia.

Osterwalder, A., Pigneur, Y., \& Clark, T. (2010). Business model generation: A handbook for visionaries, game changers, and challengers. Hoboken, NJ: Wiley.

Pateli, A. G., \& Giaglis, G. M. (2003). A framework for understanding and analyzing e-business models. 16th Bled E-Commerce Conference, Bled, Slovenia.

Ping, Y. (2010). A study on innovations of e-business models for chinese tourism industry. 2010 International Forum on Information Technology and Applications, 3, 413-416. http://dx.doi.org/10.1109/IFITA.2010.268

Pousttchi, K., Schiessler, M., \& Wiedemann, D. G. (2007). Analyzing the elements of the business model for mobile payment service provision. Sixth International Conference on the Management of Mobile Business, Torento, Canada.

Storbacka, K., \& Nenonen, S. (2010). Business model design: Conceptualizing networked value co-creation. International Journal of Quality and Service Sciences, 2(1). http://dx.doi.org/10.1108/17566691011026595

Tikkanen, H., Lamberg, J. A., Parvinen, P., \& Kallunki, J. P. (2005). Managerial cognition, action and the business model of the firm. Management Decision, 43(6). http://dx.doi.org/10.1108/00251740510603565

Weiner, N., \& Weisbecker, A. (2011). A business model framework for the design and evaluation of business models in the internet of services. Annual SRII Global Conference, San Jose, US.

Yuhang, L., \& Xiaoling, H. (2010). Comparative study of Chinese and American travel e-business models. International Conference on E-Business and E-Government, Guangzhou, China.

Zhang, J. (2009). Tourism e-commerce business model innovation analysis. International Conference on E-Business and Information System Security. EBISS '09, 1-5, Wuhan, China. http://dx.doi.org/10.1109/EBISS.2009.5138137

Zhang, Q. (2007). Application analysis and research on e-business model of China's tourism. International 
Conference on Service Systems and Service Management, Chengdu, China.

\section{Copyrights}

Copyright for this article is retained by the author(s), with first publication rights granted to the journal.

This is an open-access article distributed under the terms and conditions of the Creative Commons Attribution license (http://creativecommons.org/licenses/by/3.0/). 